УДК 331.108 .26

\title{
ОСОБЛИВОСТІ УПРАВЛІННЯ ПЕРСОНАЛОМ В IT-СФЕРІ НА ЗАСАДАХ КОРПОРАТИВНОї СОЦІАЛЬНОЇ ВІДПОВІДАЛЬНОСТІ
}

\section{FEATURES OF PERSONNEL MANAGEMENT IN THE IT SPHERE ON THE BASIS OF CORPORATE SOCIAL RESPONSIBILITY}

\author{
Журан Олена Анатоліївна, \\ кандидат економічних наук, доцент, \\ Державний університет «Одеська політехніка» \\ ORCID: https://orcid.org/0000-0001-8487-9072 \\ Лінгур Любов Миколаївна \\ кандидат економічних наук, доцент, \\ Державний університет «Одеська політехніка» \\ ORCID: https://orcid.org/0000-0002-0730-2381 \\ Філатова Тетяна В'ячеславівна \\ старший викладач, \\ Державний університет «Одеська політехніка» \\ ORCID: https//orcid.org/0000-0001-9373-4756
}

\author{
Zhuran Olena, Lingur Lyubov, Filatova Tetiana \\ Odessa Polytechnic State University
}

\begin{abstract}
Стаття присвячена актуальним питанням підбору персоналу та ефективного управління командами IT-проектів. Проаналізовані основні проблеми пошуку персоналу в IT-компаніях. Зроблено акценти на зміні мотивуючих фракторів з матеріальних на соціально відповідальні для провідних та молодих IT-спеціалістів. Розглядаються питання особливості мотивування IT-персоналу, потрібність в особливих підходах та фрактори, що мотивують, знайдуть найбільший відгук. Одним з напрямків управління командами IT-проектів пропоновано впровадження принципів корпоративної соціальної відповідальності на засадах корпоративних порталів та інформаційних систем управління бізнес-процесами. Запропоновано поширення практики стажування студентів та молодих фрахівців як ефективної фрорми залучення, відбору та підготовки персоналу відповідно вимогам IT-проектів та мотивування персоналу до підвищення кваліфікації.

Ключові слова: IT-персонал, IT-проект, IT-сорера, мотивація, Human Resource, діджиталізація, корпоративна соціальна відповідальність.
\end{abstract}

Статья посвящена актуальным вопросам подбора персонала и эффективного управления командами ИТ-проектов. Проанализированы основные проблемы поиска персонала в ИТ-компаниях. Сделаны акценты на изменении мотивирующих фракторов с материальных на социально ответственные для ведущих и молодых ИТ-специалистов. Рассматриваются вопросы особенности мотивации ИТ-персонала, необходимость в особых подходах и мотивирующие фракторы, которые найдут наибольший отклик. Одним из направлений управления командами ИТ-проектов предложено внедрение принципов корпоративной социальной ответственности на основе корпоративных порталов и информационных систем управления бизнес-процессами. Предложено распространение практики стажировки студентов и молодых специалистов как эфреектвной фрормы привлечения, отбора и подготовки персонала в соответствии с требованиями ИТ-проектов и мотивации персонала к повышению квалисрикации.

Ключевые слова: ИТ-персонал, ИТ-проект, ИТ-сфрера, мотивация, Human Resource, диджитализация, корпоративная социальная ответственность.

The article deals with the issue of personnel selection and effective management of IT project teams based on corporate social responsibility. The purpose of the article is to analyze the combination of the characteristics of ma- 
nagement and motivation of IT staff, especially when working on projects, with new trends in doing business, using the principles and mechanisms of corporate social responsibility. The study was carried out on the basis of a systematic approach to the analysis of socio-economic phenomena and processes, modern scientific trends and theories of personnel management, the development of standards of social responsibility of business and personality in the context of global digitization of the economy. To solve certain problems, analysis and synthesis methods are used when determining the main problems of motivation of IT specialists and developing recommendations to IT project managers; statistical analysis and graphical method - was used to visualize the practical results of the study. We analyzed the main problems of finding personnel in IT companies. Emphasis is placed on changing motivating factors from material to socially responsible for leading and young IT specialists. Questions about the peculiarities of IT staff motivation, the need for special approaches and motivating factors will find the most response. One of the areas of management of IT project teams is the introduction of corporate social responsibility principles based on corporate portals and business process management information systems. The use of the corporate portal will spread the awareness of employees to social responsibility, removes a number of issues of management action, determines existing and future IT projects, distributes a variety of useful information for specialists, and ultimately combines the team. Business process management information systems, especially systems with the Human Resource (HR) module and the corporate social responsibility module, allow you to accumulate, analyze personnel information and make informed recommendations on the composition of IT teams, depending on the complexity and focus of the IT project. It is proposed to spread the practice of internship of students and young specialists as an effective form of attracting, selecting and training staff in accordance with the requirements of IT projects and motivation of staff to improve their skills.

Keywords: IT staff, IT project, IT sphere, motivation, Human Resource, digitalization, corporate social responsibility.

Постановка проблеми. Інфрормаційні технології в умовах діджиталізації всіх сфер діяльності суспільства знаходять все більшого поширення, інорорматизація та цисрровізація бізнес-процесів проводиться практично у всіх без винятку сучасних компаніях, тому дослідження питання підбору та управління IT-персоналом доцільно у всіх сорерах діяльності. В умовах бурхливого розвитку цифрових технології та поширення діджиталізації усіх сторін життя суспільства, особливого значення набуває діяльність фрахівців, які створюють цифрові технології, тобто IT-спеціалісти. У будь-якій сорері діяльності персонал являє собою ключовий ресурс, особливо у IT ссрері. Головний ресурс IT-компанії як виробників та творців діджиталізації, їх головна конкурентна перевага - це кваліфрікований персонал. Майже 60-80\% собівартості послуг IT-компаній складає оплата послуг програмістів та розробників, тому їх профресійна підготовленість напряму впливає на якість проекту та імідж компанії.

Незважаючи на розвиток IT-сектору, в IT-сорері гостро стоїть питання підбору квалісікованого персоналу з необхідними знаннями, рівнем кваліфрікації та досвідом. Це обумовлює питання зниження плинності кадрів, різноманітність підходів до організації праці, дотримання принципів та норм соціально відповідального бізнесу з позицій оплати праці, соціальних гарантій, кар'єрного росту спеціалістів.

Для кожної конкретної IT-компанії важливо поєднання матеріальної й нематеріальної мотивації співробітників. Немає універсаль- ного набору мотивацій, з яких би вийшов ідеальний рецепт для утримання будь-якого розробника. Збіг сподівань внутрішньої мотивації 3 тим, що може запропонувати компанія $\epsilon$ запорукою успіху для їх довгострокового співробітництва.

Особливістю роботи в IT-компаніях $€$ командна робота. Тому все більш набирає актуальності питання не тільки підбору кваліфрікованого персоналу, а і його мотивація, злагодженість праці та коморортні соціально-психологічні обставини. В останній час ще слід додати віддаленість роботи персоналу, що накладає свої особливості в управлінні персоналом та ефективністю його роботи.

Аналіз останніх досліджень і публікацій. Основні теоретичні та практичні аспекти управлінської діяльності у тому числі і управління людьми 3 урахуванням реалій сьогодення виклали американські вчені М. Мескон, М. Альберт, Ф. Хедоури [11, с. 310].

В теорії управління вже давно вчені звернули увагу на людський капітал, як головний чинник ефрективної роботи та конкурентоспроможності організації. Зокрема, засновник школи «людських відносин» Елтон Мейо акцентував увагу на міжособистих відносинах в колективі. Значний внесок у розвиток цієї школи внесли дослідники питань мотивації, a саме: розробник ієрархічної теорії потреб (А. Маслоу) та засновник теорії мотивації, яка залежить від задоволеності або незадоволеності роботою (Ф. Герцберг).

Якщо ваш персонал працює з віддачею, 3 підвищеною емоційною установкою, то може виникнути емоційне вигорання персоналу, 
що має негативні наслідки. Згідно з моделлю М. Буріша [10, с. 32], розвиток синдрому емоційного вигорання проходить ряд стадій, тому керівник повинен завжди контролювати стан своєї команди та бути напоготові прийняти відповідні заходи ще на перших проявах емоційного вигорання.

Питаннями кадрового менеджменту, організацією та психологією управління персоналом з українських вчених слід відзначити Г. Щекіна. У своїх працях він робить акцент на соціальні аспекти в роботі з персоналом та формування сприятливого соціально-психологічного клімату в організаціях [9, с. 461]. Дослідженням проблем управління персоналом в сучасних організаціях займалися такі вітчизняні вчені як М.Д. Виноградський, О.А. Гавриш, Савельева Н.Ф. та інші [1, с. 34; 2, с. 68; 8].

Численні наукові дослідження соціальної відповідальності бізнес-структур представлені роботами Ф. Берлі, Г. Гантта, Е. Карнегі, Г. Мінза, О. Тіда, М. Фрідмана. У сучасній науці українській науці цю проблему розглядають такі вчені як В. Борисова, О. Василик, І. Давіденка, І. Кириченко, Ю. Петруніна, П. Яницький, М. Долішний, В. Гейц, В. Осецький. Проте проблеми застосування принципів корпоративної соціальної відповідальності до мотивування співробітників потребують подальшого поглибленого вивчення.

Виділення невирішених раніше частин загальної проблеми. В теперішній час більшість компаній веде проектно-орієнтовану діяльність й особливо це стосується IT-сфрери, що у свою чергу накладає свої особливості в управлінні персоналом. В сучасному світі рівень заробітної плати, це безумовно необхідний елемент, але вже недостатній для мотивації та ефрективної праці. Додаткову мотивацію створюють сучасні тренди ведення бізнесу, а саме - корпоративна соціальна відповідальність [6, с. 8]. Для IT-компанії це виконання соціально значних проектів, участь у рішенні громадських проблем, конкурсах та тендерах, які ведуть до покращення добробуту місця, регіону, країни. Таким чином, у IT-компанії створюється додатковий позитивний імідж, збільшується впізнаваність бренду. Що, в свою чергу, веде до збільшення кількості проектів, зайнятості працівників, додаткової мотивації.

Управління персоналом в IT-сфрері ключовий аспект діяльності, від того як цей процес поставлено залежить ефективність проектів, що виконуються, та діяльність компанії в цілому. 3 ростом компанії питання підбору персоналу для проектів та злагодженість їх праці стає все більш актуальніше і їх вирішенням займається окремий підрозділ - Human Resource (HR) відділ. Важливість процесу управління персоналом призводить до того, що більшість компаній IT сорери інтегрують рекрутинг до бізнес-процесів. 3 метою підвищення ефрективності роботи фрахівців HR-відділів використовують відповідні інсрормаційні системи, які автоматизують накопичення та обробку кадрової інфрормації. При таких умовах необхідна розробка методичних рекомендації щодо побудови комунікаційної складової в управлінні проектами як головного чинника успіху роботи в IT-проектах [6, с. 12].

Виходячи з викладеного матеріалу дослідження управління персоналом в IT-проектах на засадах соціальної відповідальності $\epsilon$ актуальним питанням. Незважаючи на велику кількість наукових праць, які висвітлюють проблеми управління персоналом, корпоративної соціальної відповідальності, недостатньо розкрити питання та особливості роботи 3 IT-персоналом.

Мета статті. В даному дослідженні поставлено за мету поглибити аналіз вивчення особливостей управління персоналом в IT-проектах, використання КСВ-практик в IT-компаніях, яке можливе за рахунок визначення фракторів IT-персоналу у діаграмах варіантів використання та вимог до інорормаційних HR-систем.

Викладення результатів дослідження. Одне з основних завдань фрахівців HR-відділів це забезпечення компанії фрахівцями відповідно до виставлених вимог щодо знань, компетенцій вмінь та досвіду. В умовах мінливості зовнішнього середовища та стрімкого розвитку технології, особливо в IT сорері, на передній план виходить питання актуальності отриманих знань сучасним вимогам ринку. Як вже зазначалось, у ссрері IT існує брак досвідчених фрахівців в силу молодості галузі. Тому доцільним буде в IT компаніях проводити стажування молодих фахівців. Це надає ряд переваг для майбутніх проектів:

- визначити реальні здібності кандидатів, їх знання та працездатність;

- ознайомити 3 сучасними трендами у copepi;

- надати можливість долучитися до роботи в реальних проектах;

- ознайомитися 3 компанією, особливостями її проектів, що заощадить час при залученні в наступні проекти;

- отримати креативні, свіжі погляди на реалізацію деяких задач, які стоять перед компанією. 
Однієї 3 ефрективних фрорм залучення, відбору та підготовки персоналу відповідно вимогам IT-проектів $€$ стажування студентів старших курсів IT-спеціальностей ВУЗів. Також стажування дає можливість професійним розробникам виступати у ролі менторів, ділитися своїм досвідом та фрормувати імідж компанії на ринку праці. Це відповідає принципам корпоративної соціальної відповідальності, тому що майбутні фахівці на етапі стажування знайомляться з колективом, умовами праці, оплати, соціальними гарантіями, приймають участь у діючих IT-проектах, оцінюють рівень привабливості компанії як роботодавця. В даний час ефективність роботи в IT-проектах визначається не тільки досконалим володінням професійними навичками та знаннями, а ще й особистісними якостями IT-срахівця (комунікабельність, креативність, емпатія, вміння розставляти пріоритети та інше). Попит на IT-фрахівців 3 кожним днем росте, кількість фрахівців на ринку праці теж кожен рік поповнюються молодими випускниками ВУЗів, а разом з цим росте й конкуренція. Вимоги до сучасних IT-фрахів та компетенції які вони повинні опанувати детально розглядалися у попередніх публікаціях [3, с. 197].

Робота в проектах це командна робота, тому щоб створити в командах сприятливу атмоссреру все більше роботодавці звертають увагу на особисті якості кандидатів, проводять відповідне тестування, щоб уникнути або звести до мінімуму у майбутньому міжособистісні конфрлікти.

Але і фрахівці вимагають від керівництва дотримання ряду умов: умови до устаткування, умови встановлення тривалості робочого тижня у відповідності до законодавства, встановлення здійсненних дедлайнів, додаткова оплата за понаднормову працю, за навчання і підвищення кваліфрікації нових членів команди і т. ін. Таким чином, учасники проектних команд виступають ініціаторами впровадження норм та вимог корпоративної соціальної відповідальності базисного рівня.

Розробнику потрібно бути готовим до змін зовнішнього середовища та вимог замовника й вміти приймати рішення в нестабільній ситуації. Саме гнучкість розуму і креативність, нестандартне мислення - це головні фрактори конкурентоспроможності та лідерства на ринку. У свою чергу керівникам компаній та проектів потрібно мотивувати розвиток креативності й творчості та створювати відповідні умови для персоналу, враховуючи інтереси співробітників і створюючи нові стимули.
Таким чином, компанії шукають талановитих профресіоналів, перевіряють і оцінюють в першу чергу їх професійні навички. Але тільки коли професійні та особисті якості гармонійно поєднуються в одній людині, він виростає видатним профресіоналом. Досвідчені фрахівці в свою чергу прагнуть участі не тільки у проектах 3 високою оплатою, але й у соціально значущих, відомих проектах, співпрацювати 3 трендовими IT-компаніями.

Ще одна проблема в управлінні персоналом в IT-проектах полягає в збереженні квалісрікованих срахівців. Проектні команди по своїй природі мають тимчасову структуру. Вони формуються під конкретний проект та відповідно по його закінченню розпадаються. Завдання компанії найти інше заняття срахівцям, що звільнилися. В іншому випадку в пошуках роботи фрахівці можуть перейти до іншої компанії. Нестабільність проектної команди ще раз підкреслює важливість особистих якостей розробників, бо кожний проект це різні виконавці та різні задачі.

Так, згідно проведеним опитуванням, плинність кадрів в IT-компаніях становить близько $37 \%$ за рік. Основні причини звільнення фрахівців - закінчення проектів (35\%), незадоволеність умовами праці (18\%), незадоволеність оплатою праці (12\%). Відповідно, керівники IT-компаній змушені постійно шукати нових фрахівців та залучати сторонніх виконавців для нових проектів. 3 іншого боку, IT-спеціалісти висловлюють відповідні вимоги не тільки до умов праці та заробітку, а і до змісту виконуваних проектів. Згідно опитуванню, тільки 20\% програмістів не цікавляться загальним змістом виконуваних завдань, 17\% мотивуються тільки розміром заробітної плати (опитування проводились серед працівників IT-компаній Одеси, випускників та студентів старших курсів IT спеціальностей в 2020-21 роках). Тобто, більше третини всіх IT-фрахівців працюють над створенням невідомого, можливо некорисного, вразливого програмного забезпечення. Навпроти, 53\% виконавців в IT-проектах зацікавлені в змісті завдань та в визначені суспільного та економічного внеску. Якщо керівництво IT-компаній активно впроваджує в діяльність основні норми та принципи корпоративної соціальної відповідальності базового рівня, підключається до громадських проектів, інформує громадськість та суспільство про виконані IT-проекти та участь у майбутніх, цим створюючи більш високий рейтинг як соціально-відповідального бізнеса. Ці дії підвищують загальний рейтинг IT-компанії, привертають увагу стейкхолдерів, створюють 
додаткові замовлення, зменшують плинність кадрів, грають на додаткову мотивацію фрахівців.

Кожен рік міжнародна асоціація IAOP публікує рейтинг кращих аутсорсингових компаній світу. Компанії потрапляють до рейтингу на основі заявок, в яких оцінюються прибутковість, зростання команди, кращі проекти, рекомендації замовників, рівень корпоративної соціальної відповідальності, інновації в схемі постачання послуг замовнику. Список складається в допомогу для компаній, які хочуть віддати послуги на аутсорсинг і шукають кращих і надійних партнерів для цього [12].

Аналіз показує, що все більше українських компаній присутні в цьому рейтингу, та займають доволі високі позиції. Не малу роль в оцінках грають пункти зростання команди та рівень корпоративної соціальної відповідальності. $\mathrm{Ha}$ діаграмі представлене загальний зріст кількісті IT-фрахівців в тис. чол. в українських IT-компаніях взагалі та кількість українських IT-компаній які увійшли до рейтингу (рис. 1).

Мотивація IT-срахівців, на відміну від інших профресій має свої особливості. IT-ссрера пропонує фрахівцям достатньо великий рівень заробітної плати, тому для IT-персоналу оплата праці, соціальні гарантії, територіальна доступність оорісу це обов'язкові, але не достатні критерії обрання майбутнього місця роботи. Найчастіше, це молоді люди, як показує дослідження, середній вік IT-срахівців 25-28 років, які освідченні та стежать за світовими тенденціями як у профресійній так і в суспільній ссрері [5]. Тому керівникам проектів та компаній необхідно відповідати сучасним трендам ведення бізнесу для залучення найкращих фрахівців.
IT-персонал це більш творчі люді, тому швидше відгукнуться на такі фрактори як:

- участь в цікавих проєктах, новий досвід;

- участь у соціально важливих проектах;

- можливість отримати унікальні знання, вивчати нові технології;

- робота з командою профресіоналів;

- прозоре кар'єрне зростання.

Наприклад, по підсумкам журналу Фокус, найбільш соціально-значними за останні 5 років були наступні IT-проекти: Propertymateонлайн-платорорма для покупців нерухомості, яка не тільки пропонує інфрормацію по новобудовах, а також аналізує данні по покупцях та створює прогнози по їх найбільшій зацікавленості; та український стартап ChoiZY, який присвячен профроріентації - це онлайнплаторорма, яка допомагає випускникам шкіл визначиться з майбутней професіей, а фрахівцям - ділитися своїм досвідом [13]. Ці проекти займають в рейтингу Фокуса 5 та 6 місця, поступившись проектам створення фрізичних продуктів. Але, участь в розробці таких проектів дає додатковий досвід розробникам, збільшує їх вмотивованість роботи в компанії.

Сама сорера високих технологій передова, це обумовлює присутність в ній сильних, яскравих, амбітних людей, які бажають управляти своєю кар'єрою самостійно, для яких найголовніше - це самореалізація. Й ще одна умова: для творчих людей важливі мінімум бюрократії та папірців. Їх приваблює демократичність та відкритість керівництва, й безперечно загальний позитивний клімат в організації в загалі та в команді особливо. Одним з методів та засобів реалізації таких вимог $є$ корпоративний портал

Розвиток IT компаній в Україні в 2015-2020 рр.

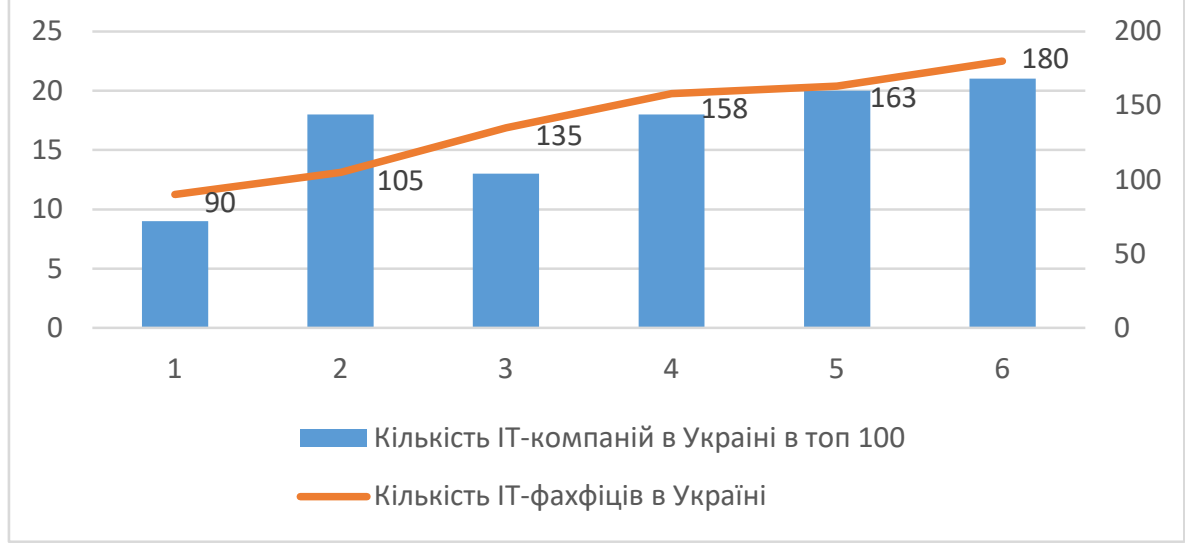

Рис. 1. Розвиток українських IT-компаній в 2015-2020

Джерело: особиста розробка авторів 
IT-компанії. Він виступає як основне джерело інфрормування про діяльність компанії, майбутні та існуючи розробки, питання корпоративного управління, трудових відносин, прав людини, охорону праці, чесні операційні практики, турботу про навколишнє середовище, роботу із зацікавленими сторонами, з якими взаємодіє компанія (співробітниками, партнерами, споживачами, державними органами, акціонерами і т.д.) [7, с. 83]. Для IT-проектів завжди було актуальним питання згуртованості та мотивування команди при віддаленій роботі. А в теперішній час карантинних обмежень питання здатності керівництва змотивувати персонал та налаштувати їх на роботу стоїть ще гостріше. В таких умовах багато залежить ще й від профресійних вмінь керівництва. Задача керівників:

- чітко сорормулювати завдання;

- ставити персоналу досяжні і зрозумілі цілі;

- вірно організувати роботу персоналу, щоб всі чітко знали що робити, як та в який термін;

- налагодити ефективний та регулярний комунікаційний зв'язок з персоналом;

- посилити контроль та звітність по виконуваним роботам.

Також слід відзначити важливість комунікаційної складової та контролю при роботі в командах та на відстані. Більш детально ці складові розглянуті у попередніх роботах авторів [4, с. 59].

Основні завдання керівників відображені на діаграмі використання користувачамикерівниками інформаційної HR-системи, 3 якою вони працюють (рис. 2).
В противному випадку неузгодженість дій команди призведе до зниження продуктивності та якості виконуваних завдань, відсутності нових креативних ідей та зриву термінів виконання роботи. Без есрективної комунікації та контролю виконання робіт керівник проекту втрачає відчуття реальності, якій поточний стан сьогодні проекту, що виконується. А в свою чергу не дає змоги вчасно прийняти необхідні запобіжні заходи та коригуючі дії.

Висновки. Діджиталізація бізнес-середовища це сучасний тренд, який останнім часом набуває характеру єдиного цифрового простору [6, с. 14]. Одночасно стандарти соціальної відповідальності бізнесу впливають на визначення нових підходів до діяльності IT-компаній в контексті розвитку цифрового суспільства та цифрової економіки. Тому IT-срахівці та IT-проекти завжди потрібні як компаніям - розробникам, так і бізнес-структурам. Розробка соціально значущих IT-проектів вимагає від розробників залучення кваліфікованих IT-фрахівців, дотримання норм трудового законодавства, використання нових, нестандартних підходів до мотивації робітників, базуючись на нових формах соціальної відповідальності. Підбиваючи підсумки, слід підкреслити, що управління персоналом в IT-проектах це непросте завдання. Для ефрективної та якісної праці команді в проектах слід враховувати велику кількість фракторів. Саме для полегшення рутинної роботи по підбору персоналу до

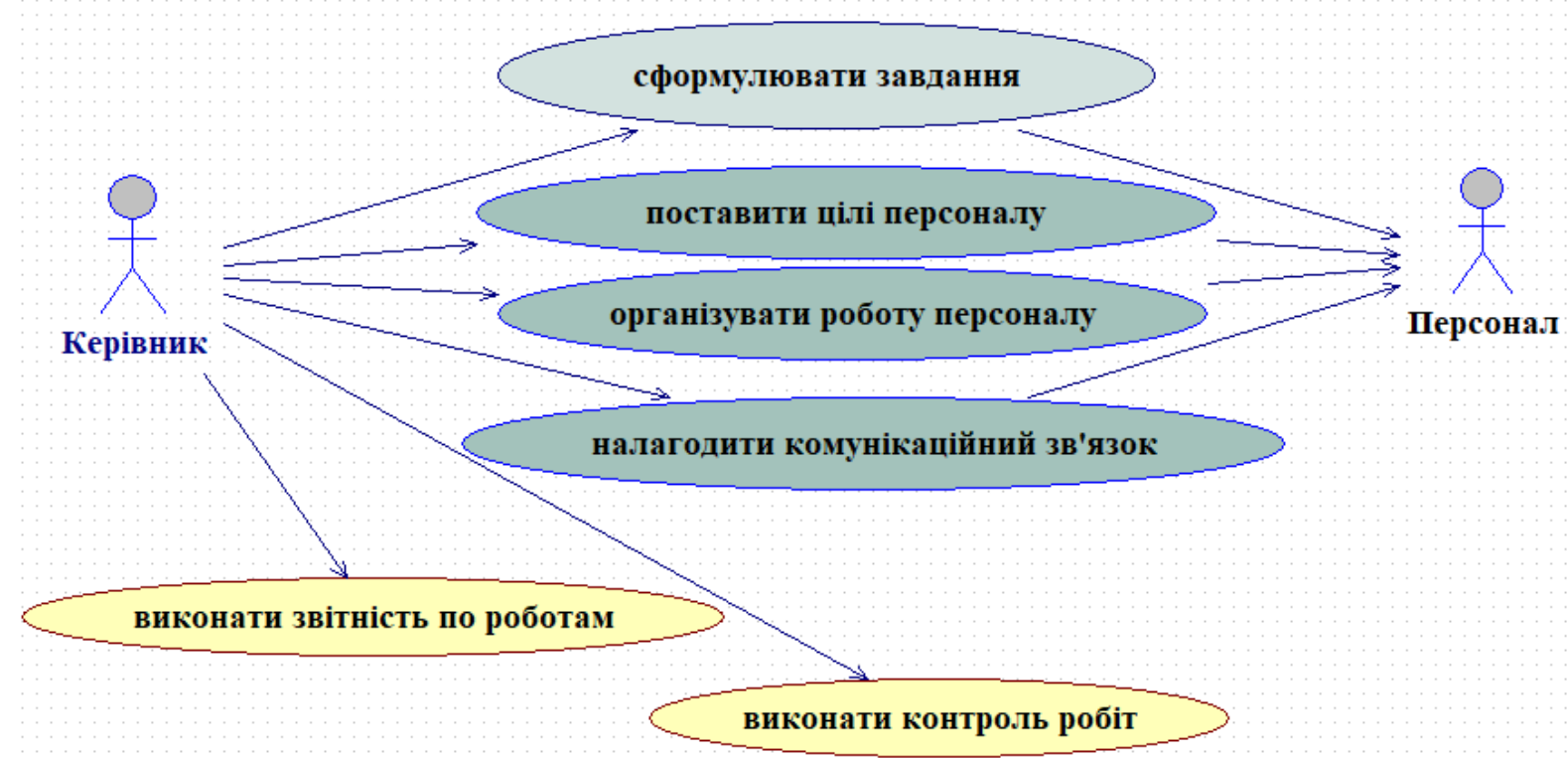

Рис. 2. Варіанти використання керівниками інформаційної HR-системи в графрічної нотації UML 
проектів доцільно використовувати відповідні інформаційні системи. На сьогодні їх достатньої велике різноманіття представлено на ринку програмного забезпечення, тому компанії можуть обирати за своїми потребами та фрінансами.

Еорективність управління персоналом напряму залежить від вміння керівника грамотно керувати накопиченим досвідом, зна- ннями та вміння персоналу, слідкувати за мікрокліматом в команді.

Найбільш вагомими мотиваційними фракторами для IT-персоналу буде можливість працювати за новітніми технологіями й впроваджувати свої, правильно побудовані процеси взаємодії всередині команди та компанії, компетентний і адекватний керівник проекту та вище керівництво компанії.

\section{СПИСОК ВИКОРИСТАНИХ ДЖЕРЕЛ:}

1. Виноградський М.Д. Управління персоналом : навч. посіб. Київ : Центр учбової літератури, 2016.

2. Гавриш О.А. Управління персоналом сучасної організації. Київ : НТУУ «КПІ», 2015.

3. Журан О.А., Філатова Т.В., Чернишов О.О. Модель формування сучасних компетенцій IT-фрахівців. Iнфрорматика та математичні методи в моделюванні. 2019. № 9(3). C. 195-202. DOI: https://doi.org/10.15276/ imms.v9.no3.195

4. Журан О.А., Донченко К.В. Управління співробітниками в умовах віддаленої роботи. Матеріали науково-практичної інтернет-конореренції «Економічна кібернетика: Теорія, практика та напрямки розвитку» (Одеса, 24-25 листопада, 2020 р.). С. 58-62. Одеса : ОНПу.

5. Ковардакова О. Особенности работы HR-специалистов в ИТ-сфрере. Инфрормационно-образовательный портал HR-tv.ru. URL: https://hr-tv.ru/articles/osobennosti-raboty-hr-spetsialistov-v-it-sfere.html

6. Лінгур Л.М. Корпоративна соціальна відповідальність малого та середнього бізнесу в умовах діджиталізації економіки : автореф. дис. канд. екон. наук. Одеса, 2021.

7. Лінгур Л.М., Кособуцька Р.О. Корпоративний портал як інструмент корпоративної соціальної відповідальності співробітників : Матеріали науково-практичної інтернет-конференції «Економічна кібернетика: Теорія, практика та напрямки розвитку» (Одеса, 27-28 листопада, 2019 р.). С. 81-84. Одеса : ОНПУ.

8. Савельева Н.Ф. Особенности управления кадрами трудовым потенциалом предприятия Известия ЮФу. Технические науки. 2005. № 8. URL: https://cyberleninka.ru/article/n/osobennosti-upravleniya-kadramitrudovym-potentsialom-predpriyatiya

9. Щёкин Г. Система управления человеческими ресурсами : монография. Київ : ГП «Издат. дом «Персонал», 2009.

10. Burisch, M. (1994) Ein integrierendes Burnout-Modell. Das Burnout-Syndrom, 117-210. DOI: https://doi.org/10.1007/978-3-662-06456-6_4

11.Mescon, M.H., Albert, M.\& Khedouri, F. Management. 3rd ed. Cambridge : Harper\&Row, 1988.

12.Сразу 21 компания из Украины вошла в мировой топ-100 лучших аутсорсеров. 2020. URL: https://ain.ua/ 2020/02/18/global-outsourcing-100-2020/

13. Изменить мир - заработать кучу денег. Топ-20 лучших стартапов Украины. 2021. URL: https://focus.ua/ ratings/478494-luchshie-startapy-ukrainy-rejting-fokusa

\section{REFERENCES:}

1. Vinogradsky, M.D. (2016) Upravlinnya personalom: navch. posib. [Personnel management: educational manual]. Kiyv: Center for Educational Literature. (in Ukrainian)

2. Gavrish, O.A. (2015) Upravlinnya personalom suchasnoy organizacii [Personnel management of a modern organization]. Kiyv: NTUU "KPI". (in Ukrainian)

3. Zhuran O.A., Filatova T.V., \& Chernyshov O.O. (2019) Model formuvannya suchasnyh kompetenciy IT-fahivciv. [Model of formation of modern competencies of IT specialists]. Informatics and mathematical methods in modeling, 9(3), 195-202. DOI: https://doi.org/10.15276/imms.v9.no3.195 (in Ukrainian)

4. Zhuran, O.A., Donchenko, K.V. (2020) Upravlinnya spivrobitnykami v umovah viddalenoi roboty [Management of employees in the conditions of remote work]. Proceedings from TSAPE' 16: Naukovo-praktychna internet-konferenciya «Economichna kibernetyka: teoriya, praktyka ta napryamky rozvytku» - The Scientific and Practical Internet Conference «Economic Cybernetics: Theory, Practice and Directions of Development» (Odessa, November 24-25th, 2020), pp. 58-62. Odessa: ONPU. (in Ukrainian)

5. Kovardakova, O. Osobennosti raboty HR-specialictov v IT-sfere [Features of work of HR-specialists in the IT sphere]. Information and educational portal HR-tv.ru. Retrieved from: https://hr-tv.ru/articles/osobennosti-raboty-hr-spetsialistov-v-it-sfere.html (in Russian) 
6. Lingur, L.M. (2021) Korporatyvna socialna vidpovidalnist maloho ta sredneho biznesu v umovah didjitalizacii ekonomiki [Small and medium business corporate social responsibility in the context of economy digitalization]. Extended abstract of Candidate's thesis. Odessa. (in Ukrainian)

7. Lingur, L.M. Kosobucka, R.O. (2019) Korporatyvnyi portal yak instrument korporatyvnoi socialnoi vidpovidalnosti spivrobitnykiv [Corporate portal as a tool of corporate social responsibility of employees]. Proceedings from TSAPE' 16: Naukovo-praktychna internet-konferenciya «Economichna kibernetyka: teoriya, praktyka ta napryamky rozvytku» - The Scientific and Practical Internet Conference «Economic Cybernetics: Theory, Practice and Directions of Development» (Odessa, November 27-28th, 2019), pp. 81-84. Odessa: ONPU. (in Ukrainian)

8. Savelyeva, N.F. (2005) Osobennosti upravleniya kadrami trudovym potencialom predpriyatiya [Features of personnel management of labor potential of the enterprise]. Izvestia SFU. Technical sciences, no. 8. Retrieved from: https://cyberleninka.ru/article/n/osobennosti-upravleniya-kadrami-trudovym-potentsialom-predpriyatiya (in Russian)

9. Shchekin G. (2009) Sistema upravleniya chelovecheskimi resursami [Human resources management system]. Kiyv: GP «lzdat. House "Staff". (in Ukrainian)

10. Burisch, M. (1994) Ein integrierendes Burnout-Modell. Das Burnout-Syndrom, 117-210. DOI: https://doi.org/10.1007/978-3-662-06456-6_4

11.Mescon, M.H., Albert, M., \& Khedouri, F. (1988) Management (3rd ed.). Cambridge: Harper\&Row. 